\title{
Ovarian tissue transport to expand access to fertility preservation: from animals to clinical practice
}

\author{
Francesca E Duncan¹, Mary Zelinski², Alexander H Gunn, Jennifer E Pahnke, \\ Conor L O’Neill ${ }^{1}$, Nucharin Songsasen ${ }^{3}$, Ryan I Woodruff ${ }^{1}$ and Teresa K Woodruff ${ }^{1}$ \\ ${ }^{1}$ Department of Obstetrics and Gynecology, Feinberg School of Medicine, Northwestern University, \\ Chicago, Illinois, USA, ${ }^{2}$ Oregon National Primate Research Center, Beaverton, Oregon, USA, and \\ ${ }^{3}$ Smithsonian Conservation Biology Institute, Front Royal, Virginia, USA \\ Correspondence should be addressed to T K Woodruff; Email: tkw@northwestern.edu
}

\begin{abstract}
Primordial follicles dictate a female's reproductive life span and therefore are central to fertility preservation for both endangered species and individuals with fertility-threatening conditions. Ovarian tissue containing primordial follicles can be cryopreserved and later thawed and transplanted back into individuals to restore both endocrine function and fertility. Importantly, increasing numbers of human live births have been reported following ovarian tissue cryopreservation and transplantation. A current limitation of this technology is patient access to sites that are approved or equipped to process and cryopreserve ovarian tissue - especially in larger countries or low resource settings. Here, we review empirical evidence from both animal models and human studies that suggest that ovarian tissue can be transported at cold temperatures for several hours while still maintaining the integrity and reproductive potential of the primordial follicles within the tissue. In fact, several human live births have been reported in European countries using tissue that was transported at cold temperatures for up to $20 \mathrm{~h}$ before cryopreservation and transplantation. Ovarian tissue transport, if implemented widely in clinical practice, could therefore expand both patient and provider access to emerging fertility preservation options.
\end{abstract}

Reproduction (2016) 152 R201-R210

\section{Introduction}

Chemotherapy and radiation therapy, although used successfully to treat a myriad of malignant and nonmalignant conditions, can have the unintended longterm consequence of damaging reproductive function (Lobo 2005, Meirow et al. 2005, Jeruss \& Woodruff 2009, Woodruff 2010, Hirshfeld-Cytron et al. 2011, De Vos et al. 2014, Wallace et al. 2014). In females, these treatments can negatively affect several aspects of the reproductive system, including the hypothalamicpituitary-gonadal axis, the ovary and the uterus (Gracia \& Woodruff 2012, Duncan et al. 2014). Impaired reproductive function can ultimately result in infertility, sterility and other outcomes, including depression, psychological disorders and sexuality issues (Canada \& Schover 2012, Gracia \&Woodruff 2012, Lewis et al. 2012, Chambers et al. 2013, Milbury et al. 2013, Lawson et al. 2014, Morrow et al. 2014, Levine et al. 2015). To avoid some of these consequences, fertility preservation strategies have been developed and are being implemented in clinical practice (Waimey et al. 2013, De Vos et al. 2014).

The American Society for Clinical Oncology (ASCO) and the American Society for Reproductive Medicine
(ASRM), along with the American Academy of Pediatrics and the European Society of Human Reproduction and Embryology (ESHRE), have all recognized the need to address the potential threat of gonadotoxic treatments to fertility, each assembling expert committees and publishing guidance documents emphasizing the need for consultation at the time of diagnosis and rapid referral of patients to reproductive endocrinology and infertility specialists (Ethics Committee of American Society for Reproductive Medicine 2013, Loren et al. 2013). To date, female fertility preservation options that are recognized by ASCO and the ASRM/ESHRE are limited to embryo and egg cryopreservation (Ethics Committee of American Society for Reproductive Medicine 2013, Loren et al. 2013). Although these assisted reproductive technology (ART) procedures are successful, they may not be available to all patients. For example, embryo and egg freezing are not possible or are contraindicated in prepubertal females or those who cannot delay treatment for their primary condition (Jeruss \& Woodruff 2009). For these patients, one experimental fertility preservation option is ovarian tissue cryopreservation (OTC) (Backhus et al. 2007, Chen et al. 2014, De Vos et al. 2014, Dolmans et al. 2014, Ross et al. 2014, 
Stoop et al. 2014, Suzuki et al. 2015). OTC involves the removal of a whole ovary or cortical biopsies that are then cryopreserved by either slow freezing or vitrification (Rosendahl et al. 2011, Ting et al. 2013, Suzuki et al. 2015). This tissue can be thawed at a later date and used to restore reproductive function (Backhus et al. 2007, Chen et al. 2014, De Vos et al. 2014, Dolmans et al. 2014, Ross et al. 2014, Stoop et al. 2014). OTC followed by orthotopic or heterotopic transplantation has resulted in restoration of endocrine function and fertility, with at least 60 live human births reported to date (Smitz et al. 2010, Gamzatova et al. 2014, Dittrich et al. 2015, Donnez \& Dolmans 2015). Although OTC and ovarian tissue transplantation have resulted in live human births, this technology is still considered investigational and may be associated with a reintroduction of the cancer the patient has just survived. As with all experimental technologies, this procedure can only be performed under appropriate ethical protocols.

Despite the investigational designation of OTC, there has been an upward trend in the interest in and use of this technology. In the USA, the National Physicians Cooperative (NPC), which is part of the Oncofertility Consortium, is a nationwide infrastructure of clinical and allied sites committed to providing personalized fertility preservation care (Gracia \& Woodruff 2012, Gracia et al. 2012) (http://www.oncofertility.northwestern. edu/health-professionals/npc-membership-info-andnpc-resources). Several NPC sites offer OTC under institutional review board (IRB)-approved protocols, and the number of OTC cases reported through the NPC has increased steadily in the past decade (Duncan et al. 2015). Interestingly, and perhaps not surprisingly, the largest increase in the use of OTC in the NPC has occurred in the pediatric and young adult population, potentially because of increased awareness about this option and the expanding list of medical conditions and treatments that can compromise fertility (HirshfeldCytron et al. 2011, Duncan et al. 2015).

The ability to perform OTC requires trained staff, specialized equipment, designated space and time to prepare the ovarian cortex and to freeze it using specified protocols (Backhus et al. 2007, American Society for Reproductive Medicine 2014). Because of these requirements, the number of clinical sites that offer OTC for fertility preservation remains low. One approach to increasing patient access to OTC is to facilitate efficient ovarian tissue transport. The concept of preserving organ viability during transport has been instrumental for life-saving transplantation of organs, including kidneys, liver, pancreas, lungs and heart. The most common organ preservation technique for transport is induced hypothermia to approximately $4^{\circ} \mathrm{C}$ (Cantu \& Zaas 2011). Hypothermia suppresses metabolism and catabolic enzymes, such that with each $10^{\circ} \mathrm{C}$ drop in temperature, the metabolic rate is halved (Cantu \& Zaas 2011). As a result, at $4^{\circ} \mathrm{C}$, the remaining metabolic rate is approximately $10 \%$ of normal (Cantu \& Zaas 2011). The lower metabolic rate reduces mitochondrial enzyme activity, which in turn reduces the accumulation of lactic acid and slows down the decrease in intracellular $\mathrm{pH}$, proteolysis, lipolysis and lipid peroxidation associated with ischemia (Guibert et al. 2011). Induced hypothermia protects organs from damage while they are removed from the blood supply, but perhaps not surprisingly, the maximum time of preservation at cold temperatures varies depending on the specific organ (Guibert et al. 2011). Specifically, the heart (6h) and the lungs $(8 \mathrm{~h})$ have the lowest tolerance for cold ischemia, whereas the liver (12-15 h) and kidneys (24h) have the highest (Guibert et al. 2011).

Ovarian transplantation as a clinical concept has been in existence since the late 1800s; yet, it has lagged behind other organ systems (Rodriguez \& CampoEngelstein 2011). Although cold storage transport is used widely for kidneys, liver, pancreas, lungs and heart, it is not yet standard of care for ovaries in the setting of fertility preservation. However, two European countries - first Denmark and subsequently Germany have successfully pioneered the clinical use of ovarian tissue transport (Dittrich et al. 2012, 2015, Muller et al. 2012, Bastings et al. 2014, Jensen et al. 2015). They describe this model, which has been ongoing for 10 years, as 'the woman stays - the tissue moves' (Jensen et al. 2015). In this process, ovarian tissue is removed and prepared at a local hospital and then transported to an approved site where the cryopreservation procedure is performed. Following cryopreservation, the tissue is stored for the individual's future use. Ovarian tissue transport is particularly challenging because there are several structures and cell types within the tissue that need to be maintained in a healthy state. The ovarian cortex is of particular interest because it is enriched in primordial follicles, which comprise a female's ovarian reserve and dictate her reproductive life span (Schmidt et al. 2003a). Once the thawed tissue is transplanted, it is these dormant follicles that will eventually grow, produce hormones and restore reproductive function and fertility. The success of clinical ovarian tissue transport in Europe demonstrates that cold storage of ovarian tissue is efficacious.

Integrating ovarian tissue transport into fertility preservation protocols would expand access to OTC by allowing remote or small clinical practices that may not have resources or staff, the ability to offer this option to their patients. This is especially important in large countries and/or in low resource settings. Additionally, some patients may not have the time to delay treatment for their primary condition in order to travel to a site that offers OTC, or they may not want to seek fertility preservation at a different and/or distant institution. Ovarian tissue transport would overcome these barriers and expand the fertility preservation options available to these patients. In this review, we highlight the 
current status of ovarian tissue transport, first discussing research findings in domestic animals and preclinical studies with human tissue, and then presenting clinical results documenting live births following ovarian tissue transport, OTC and transplantation of the thawed tissue. Taken together, there is strong empirical evidence supporting the safe and efficient use of ovarian tissue transport for fertility preservation.

\section{Evidence from animal studies}

The mouse is a critical research model, and recently, a comprehensive study was performed that interrogated the effect of storage temperature and duration on ovarian tissue function (Kamoshita et al. 2016). Storage at $4^{\circ} \mathrm{C}$ for up to $24 \mathrm{~h}$ did not significantly affect the histological morphology of the tissue or the number of mature gametes that could be collected or fertilized post-orthotopic transplantation (Kamoshita et al. 2016). However, cold storage did significantly reduce the incidence of implantation and live offspring (Kamoshita et al. 2016). The findings from this mouse study, while important, should be interpreted with caution because the mouse ovary is fundamentally different from ovaries in large mammalian species - especially in terms of architecture and size.

Studies on large animal models have demonstrated that the transport of ovarian tissue is possible without harming the pool of primordial follicles (Baird et al. 1999, 2004, Onions et al. 2008, Alves et al. 2015, Salih et al. 2015). Although the majority of studies focus on the health of fully grown oocytes as an end point of ovarian tissue transport (see section on 'Effect of ovarian tissue transport on oocytes from antral follicles'), some have analyzed the effect of the transport time and temperature specifically on the population of preantral follicles (Silva et al. 2000, Lucci et al. 2004, Lopes et al. 2009, Lima et al. 2010, Gomes et al. 2012). For example, in goats, transport of ovarian tissue at $4^{\circ} \mathrm{C}$ for up to $24 \mathrm{~h}$ maintained morphologically normal primordial follicles (Silva et al. 2000). Once the temperature was increased to $20^{\circ} \mathrm{C}$ or $39^{\circ} \mathrm{C}$, or the time was extended past $24 \mathrm{~h}$, however, there was a significant loss of primordial follicles (Silva et al. 2000). These results are consistent with work done on zebu cow ovaries. When ovarian tissue was stored at $4^{\circ} \mathrm{C}$ for up to $18 \mathrm{~h}$, more than $90 \%$ of the preantral follicles exhibited normal structure and morphology (Lucci et al. 2004). When the ovarian tissue was stored at $20^{\circ} \mathrm{C}$ and for longer than $6 \mathrm{~h}$, the morphology of preantral follicles in the ovarian tissue significantly diminished (Lucci et al. 2004). In the canine model, one study concluded that ovarian storage at $4^{\circ} \mathrm{C}$ for up to $12 \mathrm{~h}$ provides optimal preservation conditions for preantral follicles and ensures the maintenance of morphology and viability of these follicles (Lopes et al. 2009). This observation is supported by another study that found that when ovarian tissue was held between $3^{\circ} \mathrm{C}$ and $9{ }^{\circ} \mathrm{C}$, more than $80 \%$ of the primordial follicles appeared normal and viable. After $36 \mathrm{~h}$ at these temperatures, however, only $59.8 \%$ of the primordial follicles survived (Lima et al. 2010). More recently, a study with equine ovarian tissue concluded that increasing the time and temperature of tissue transport significantly reduced the percentage of morphologically normal follicles (Gomes et al. 2012). The greatest percentage of viable follicles was found in equine ovarian tissue that was transported at $4^{\circ} \mathrm{C}$ for $4 \mathrm{~h}$.

Ongoing work through the NPC is consistent with this published data in large animal models. For example, we have examined the transport of bovine, feline and canine tissue at 4,25 and $37^{\circ} \mathrm{C}$ for $24 \mathrm{~h}$. In each of the ovarian tissue types, our histological analysis found that the structure and morphology of primordial and preantral follicles were best maintained when the ovarian tissue was kept at 4 or $25^{\circ} \mathrm{C}$ (Figs 1 and 2). In our experience, antral follicles were compromised under all transport conditions as evidenced histologically by the disruption of the integrity of the cumulus-oocyte complex (COC) (Fig. 2; see section on 'Effect of ovarian tissue transport on oocytes from antral follicles').

Some of the most convincing evidence supporting the clinical use of ovarian tissue transport in the setting of fertility preservation comes from the nonhuman primate model. A recent study determined that transport of primate ovarian tissue at $4^{\circ} \mathrm{C}$ for up to $24 \mathrm{~h}$ did not compromise the quality of the tissue or the health of the follicles (Hornick et al. 2012). When compared with freshly fixed controls, morphology markers in the transported ovarian tissue were indistinguishable and there were no differences in the number of apoptotic cells (Hornick et al. 2012). In addition, follicles isolated from these transported tissues survived and grew in an encapsulated in vitro follicle growth (IVFG) system that recapitulates oogenesis and folliculogenesis, demonstrating the functionality of these cells after transport (Hornick et al. 2012). Thus taken together, there was better preservation of primordial follicles than of developing follicles at colder temperatures in ovarian tissue from most large animal models. Because the majority of primordial follicles are presumably quiescent, it is possible that they may be less affected by the reduced cellular metabolism rate at cooler temperatures (Silva et al. 2000, Gomes et al. 2012). In addition, the less complex cellular structure as well as the smaller oocyte volume may also contribute to the relative resilience of primordial follicle to cold temperatures.

\section{Evidence from preclinical studies with human ovarian tissue}

The ovarian tissue transport studies performed in animal models have been replicated successfully with 

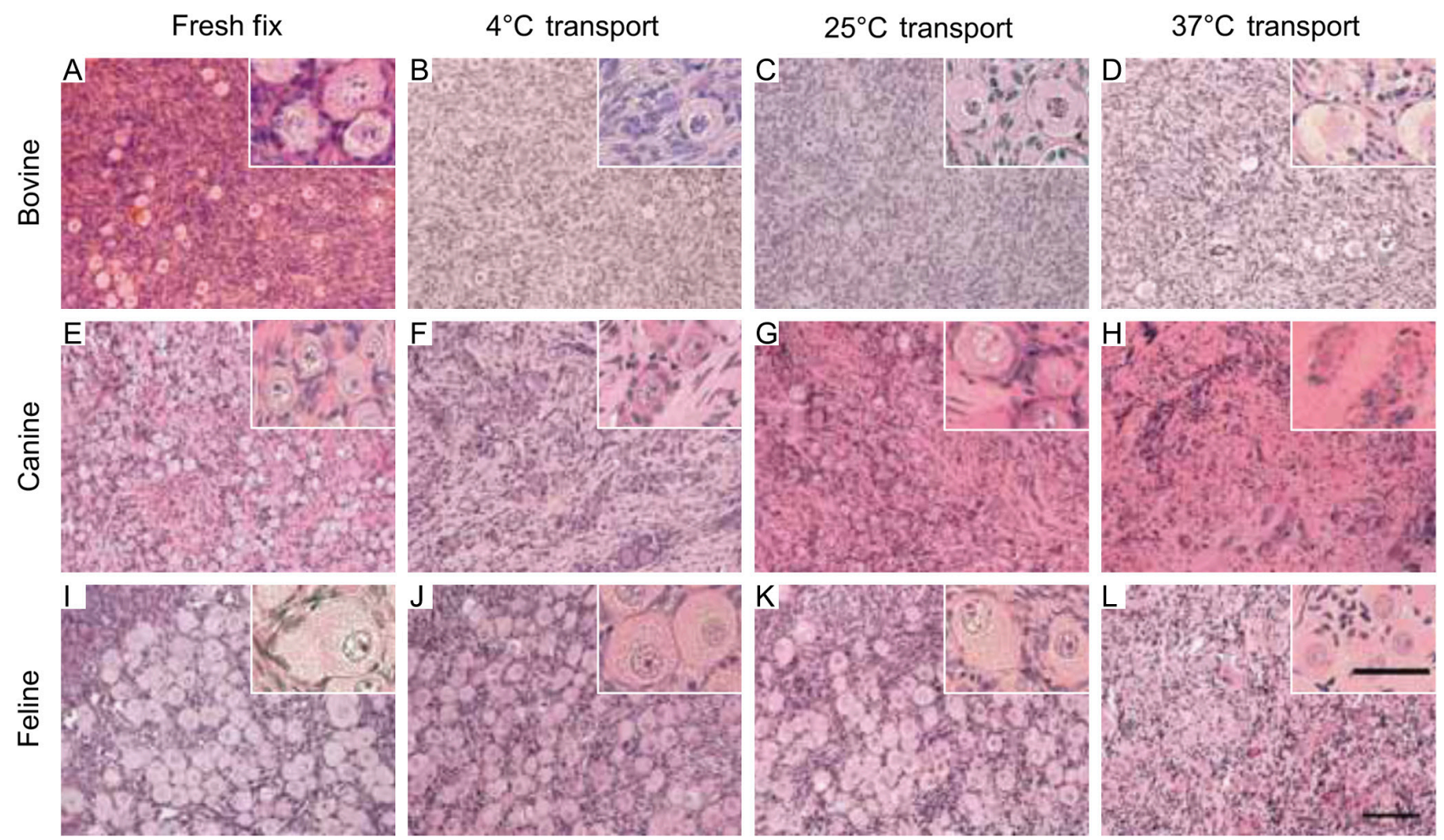

Figure 1 Ovarian tissue transport at colder temperatures maintains primordial follicle morphology in multiple species. Bovine (A-D), canine $(\mathrm{E}-\mathrm{H})$ and feline $(\mathrm{I}-\mathrm{L})$ ovarian tissue was harvested from individual animals and divided. One piece of tissue was fixed immediately upon organ removal $(\mathrm{A}, \mathrm{E}$ and $\mathrm{I})$, and the remaining pieces were transported at $4{ }^{\circ} \mathrm{C}(\mathrm{B}, \mathrm{F}$ and $\mathrm{J}), 25^{\circ} \mathrm{C}(\mathrm{C}, \mathrm{G}, \mathrm{K})$ and $37^{\circ} \mathrm{C}(\mathrm{D}, \mathrm{H}$ and $\mathrm{L})$ for $24 \mathrm{~h}$. In this manner, the only variable was transport temperature. Following transport, the ovarian tissue was fixed and the morphology of the primordial follicles within the ovarian cortex was examined by standard histological evaluation by hematoxylin and eosin staining. Primordial follicle integrity was compromised in all species following transport at $37^{\circ} \mathrm{C}$. However, primordial follicles at both 4 and $25^{\circ} \mathrm{C}$ looked similar to fresh fixed controls. These experiments were repeated a minimum of three times and representative images are shown. Scale bar $=50 \mu \mathrm{m}$. The insets are higher magnification images, which highlight the morphology of the primordial follicles.

human ovarian tissue by several groups (Schmidt et al. 2003b, Isachenko et al. 2009, Laronda et al. 2014). The transport of human ovarian tissue at cold temperatures and within a period of $4-26 \mathrm{~h}$ maintains functional parameters of the tissue as assessed by morphology, viability and follicle development in vitro and in vivo (Schmidt et al. 2003b, Isachenko et al. 2009, Laronda et al. 2014). In one recent study, ovarian cortical tissue from 24 individuals was transported for up to $22 \mathrm{~h}$ at $4^{\circ} \mathrm{C}$, and cell quality and morphology were compared in histological and TUNEL analyses to pre-transport control tissue from the same individual (Laronda et al. 2014). In more than half of the samples, the transported tissue was histologically similar to the freshly fixed control tissue, and TUNEL analysis demonstrated a similar percentage of apoptotic cells in the pre- and post-transport tissues. In some samples, significantly more TUNEL-positive cells were observed in the post-transport tissue compared with freshly fixed control tissue. These TUNEL-positive cells, however, were primarily constrained to the edge of the tissue. Preantral follicles at the secondary follicle stage isolated from this transported human ovarian tissue were able to survive and grow to the antral stage in culture and to develop with normal morphology (Laronda et al. 2014).

The findings from the study by Laronda et al. (2014) are consistent with another study that also evaluated the quality of transported human ovarian tissue using an IVFG assay (Isachenko et al. 2009). In that study, storage of ovarian cortical fragments at suprazero temperatures for up to $26 \mathrm{~h}$ did not compromise the in vitro development of follicles during subsequent culture of intact tissue pieces (Isachenko et al. 2009). Interestingly, the storage of human ovarian cortex at $5^{\circ} \mathrm{C}$ for $24 \mathrm{~h}$ before cryopreservation increased the viability of the follicles after thawing as assessed by culture in the chorioallantoic membrane system followed by immunohistochemical analysis of proliferation marker expression within the cultured tissue (Isachenko et al. 2013). Immunohistochemical analysis of ovarian tissue after $24 \mathrm{~h}$ at $5^{\circ} \mathrm{C}$ also showed that neovascularization was increased compared with non-cooled control tissue, which is important because this process is critical for implantation and function of transplanted ovarian tissue (Isachenko et al. 2012). The physiological basis for these phenomena, however, is unclear. Moreover, without evaluation of the number and viability of follicles as 
Fresh fix
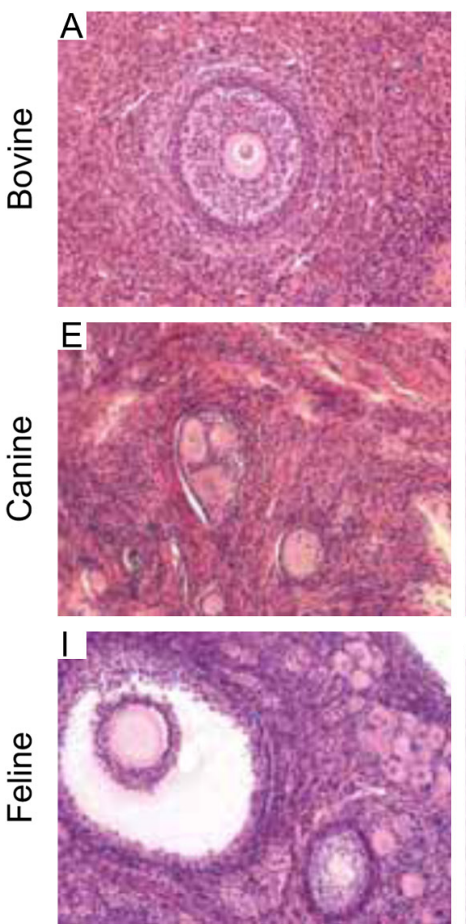

$4^{\circ} \mathrm{C}$ transport
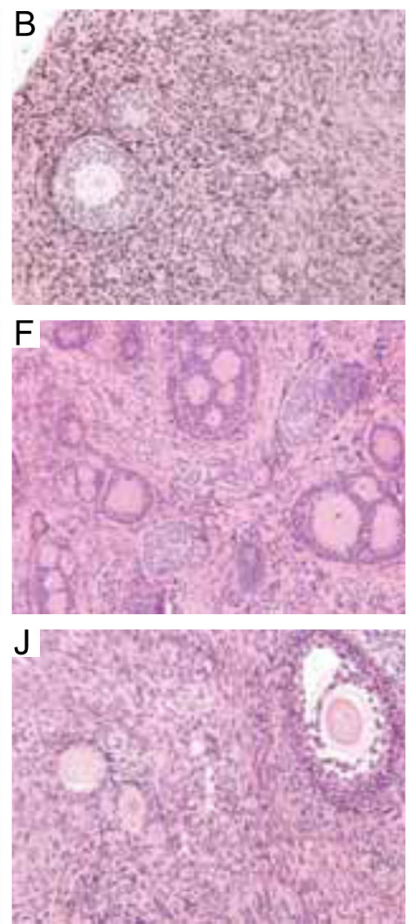

$25^{\circ} \mathrm{C}$ transport
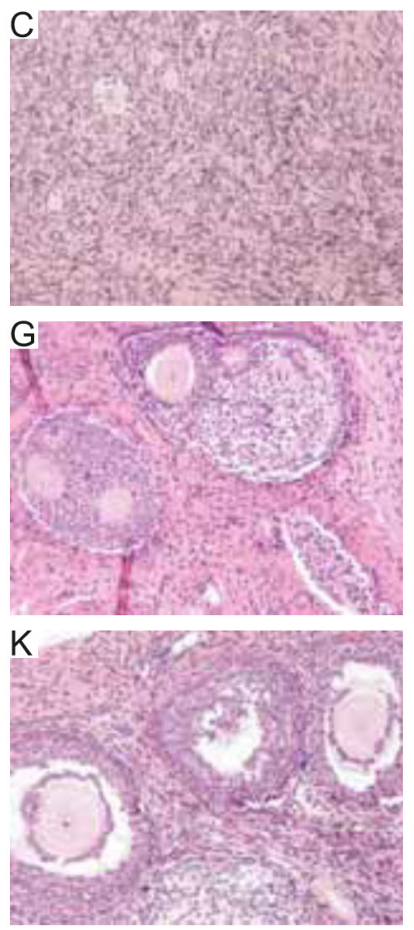

$37^{\circ} \mathrm{C}$ transport
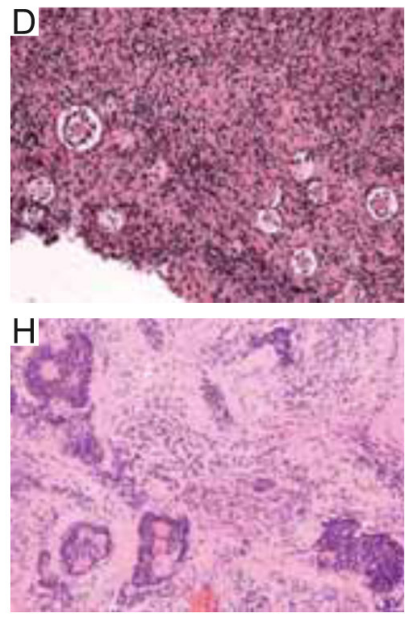

L

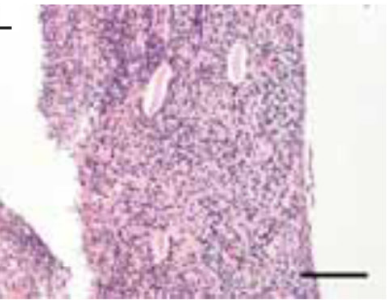

Figure 2 Ovarian tissue transport at colder temperatures maintains preantral follicle morphology in multiple species. Bovine (A-D), canine (E-H) and feline $(\mathrm{I}-\mathrm{L})$ ovarian tissue was harvested from individual animals and divided. One piece of tissue was fixed immediately upon organ removal (A, E and I), and the remaining pieces were transported at $4{ }^{\circ} \mathrm{C}(\mathrm{B}, \mathrm{F}$ and $\mathrm{J}), 25^{\circ} \mathrm{C}(\mathrm{C}, \mathrm{G}$ and $\mathrm{K})$ and $37^{\circ} \mathrm{C}(\mathrm{D}, \mathrm{H}$ and $\mathrm{L})$ for $24 \mathrm{~h}$. In this manner, the only variable was transport temperature. Following transport, the ovarian tissue was fixed and the morphology of the preantral follicles within the ovarian tissue was examined by standard histological evaluation by hematoxylin and eosin staining. Preantral follicle integrity was significantly compromised in all species following transport at $37^{\circ} \mathrm{C}$. However, preantral follicles at both 4 and $25^{\circ} \mathrm{C}$ looked similar to fresh fixed controls. Antral follicles did not appear to tolerate any transport conditions. This is highlighted in the feline sample where disruption of the cumulus layer surrounding the oocyte was evident following transport ( $\mathrm{J}$ and $\mathrm{K}$ ) but not in the control (I). These experiments were repeated a minimum of three times and representative images are shown. Scale bar $=50 \mu \mathrm{m}$.

well as the extent of vascularization in the tissue pieces before experimental manipulation, it is impossible to conclude whether cooling per se had a significant effect on these parameters.

Reports of consistent histology and IVFG following transport are robustly supported by the successful xenotransplantation of human ovarian tissue that was transported before cryopreservation (Schmidt et al. $2003 b$ ). Following transport on ice for approximately $4 \mathrm{~h}$, ovarian tissue was cryopreserved, then thawed and xenotransplanted into a mouse. After 4 weeks, each of the transplanted pieces of ovarian tissue was recovered and found to contain healthy follicles at the primordial, primary and secondary stages (Schmidt et al. 2003b). This work is of particular significance because it demonstrates the function of the transported, cryopreserved, thawed and transplanted tissue in an in vivo model. Taken together, this research demonstrates that transport of human ovarian tissue at or around $4^{\circ} \mathrm{C}$ before cryopreservation maintains the primordial follicle pool and may even have a positive effect on the subsequent growth and development of the follicles within the tissue (Schmidt et al. 2003b, Isachenko et al. 2013, Laronda et al. 2014).

\section{Clinical studies}

The strongest unequivocal support of the safety and efficacy of ovarian tissue transport are the live births that have been reported after transplantation of transported ovarian tissue. Transplantation of ovarian tissue has led to at least 60 live births to date, and several of these were achieved after transplantation of ovarian tissue that was transported for up to $22 \mathrm{~h}$ before cryopreservation (Andersen et al. 2008, Ernst et al. 2010, Rosendahl et al. 2011, Dittrich et al. 2012, Muller et al. 2012, Dittrich et al. 2015, Donnez \& Dolmans 2015, Jensen et al. 2015). These cases indicate that transport before cryopreservation does not compromise the functional potential of the tissue. Moreover, these reports demonstrate that (1) live births can be obtained following cold tissue transport at $4^{\circ} \mathrm{C}$, (2) tissue can be transported up to $20 \mathrm{~h}$ and remain viable and (3) multiple live births can be obtained from the same tissue.

In several European countries, primarily Denmark and Germany, ovarian tissue transport has been combined with OTC and transplantation with successful clinical outcomes. In Denmark, OTC is only performed at the Laboratory of Reproductive Biology at Copenhagen 
University Hospital, Rigshospitalet, which provides a centralized localization (Rosendahl et al. 2011). Ovaries removed from patients at other centers around the country must be placed on ice and transported by airfreight, train or car within $4-5 \mathrm{~h}$ to the Copenhagen University Hospital for cryopreservation. As of 2015, this program performed 53 transplantations to 41 patients over the course of 10 years, and nine of these women had a tissue that was transported on ice before cryopreservation (Jensen et al. 2015). This group reports a pregnancy rate of $\sim 30 \%$ using this technology, again supporting the combined use of ovarian tissue transport with OTC and transplantation (Jensen et al. 2015).

Two case reports from the Danish and German experiences are described in more detail below because they highlight the longevity and functionality of ovarian tissue grafts post-transport and illustrate the relative resistance of ovarian tissue to cold transport. In the first case from Denmark, a 27-year-old woman who had been diagnosed with Ewing's sarcoma had undergone OTC for fertility preservation. The patient's ovarian tissue was transported on ice for $5 \mathrm{~h}$ and then cryopreserved for 21 months. For the ovarian transplantation procedure, tissue corresponding to approximately $15-20 \%$ of one entire ovary was transplanted into subperitoneal pockets in the patient's parietal peritoneum (Andersen et al. 2008, Ernst et al. 2010). This woman had two healthy girls from this tissue, making her the first patient to have two separate pregnancies and births resulting from a single OTC-autotransplantation procedure. At the time of OTC, the woman only had her right ovary because the left one had been removed previously due to a dermoid cyst. A part of the right ovary was removed for OTC. Although it is possible that the pregnancies resulted from residual ovarian tissue rather than the transplanted tissue, a biopsy of the remaining ovary was performed at the time of transplantation, and no follicles were found by histological examination.

In the second case from Germany, a live birth following ovarian tissue cryopreservation and transplantation was reported after $20 \mathrm{~h}$ of cold transport, suggesting that the ovary is similar to the kidneys and liver in terms of its tolerance to cold temperatures (Dittrich et al. 2012, Guibert et al. 2011). In this case, a 25-year-old woman with nodular sclerosing Hodgkin lymphoma had twothirds of the ovarian cortex from each ovary removed, and the tissue was transported at $5-8^{\circ} \mathrm{C}$ for $20 \mathrm{~h}$ from Dresden University Hospital to the Reproductive Medicine Laboratory in Bonn for cryopreservation (Dittrich et al. 2012). After 5 years of cryopreservation, the tissue was transplanted into a deep pouch of the peritoneum in the region of the broad ligament. The patient had a spontaneous pregnancy and delivered a healthy male (Dittrich et al. 2012). During the cesarean section, the research team stated that healthy follicles were clearly visible on the surface of the transplanted tissue (Muller et al. 2012). Further, biopsy samples taken from the transplanted ovarian tissue revealed numerous follicles in all stages of development. This histological analysis confirms the viability of ovarian tissue that had been transported up to $20 \mathrm{~h}$ at $4^{\circ} \mathrm{C}$ before cryopreservation (Muller et al. 2012).

Thus, it is clear that in the short time that ovarian tissue transport protocols have been employed in Europe, there have been multiple live births following autotransplantation (Andersen et al. 2008, Ernst et al. 2010, Rosendahl et al. 2011, Dittrich et al. 2012, Muller et al. 2012, Dittrich et al. 2015, Jensen et al. 2015). These impressive clinical results illustrate the potential for integrating ovarian tissue transport before cryopreservation as a way to expand global access to OTC.

\section{Effect of ovarian tissue transport on oocytes from antral follicles}

The majority of this review has focused on ovarian tissue transport conditions that favor the preservation of preantral follicles. However, ovarian tissue also contains antral follicles at various stages of development. Cumulus-oocyte complexes (COCs) from both small and large antral follicles can be isolated directly from harvested ovarian tissue and matured in vitro to obtain mature gametes. In fact, COCs in the ovarian medulla are often released from antral follicles during cortical ovarian tissue processing for OTC and can be used for fertility preservation if they are from follicles that have reached adequate maturity and if they are of high quality (Revel et al. 2003, Duncan et al. 2012). Mature eggs derived from IVM can be cryopreserved or fertilized and then cryopreserved as embryos. In vitro maturation (IVM) is another promising fertility preservation option, and importantly, pregnancies and live births have been obtained using this method (Guzman et al. 2012, Chian et al. 2013, Segers et al. 2015, Uzelac et al. 2015).

In animal studies, the data regarding how well COCs withstand cold transport are not consistent. In one study, bovine ovaries were transported for 3-4h at 15, 25 and $35^{\circ} \mathrm{C}$; oocytes from the ovaries transported at $15^{\circ} \mathrm{C}$ had a higher developmental competence and lower apoptotic index compared with the other transport groups (Wang et al. 2010). In the canine model, oocytes obtained from ovaries transported for up to $4 \mathrm{~h}$ at $4^{\circ} \mathrm{C}$ had a significantly higher MII maturation rate than those transported at $35-38^{\circ} \mathrm{C}$ (Tas et al. 2006). However, in another study, transport at $37^{\circ} \mathrm{C}$ for up to $8 \mathrm{~h}$ resulted in the greatest oocyte viability, although this study did not directly compare outcomes with oocytes from ovarian tissue transported at $4{ }^{\circ} \mathrm{C}$ (Hanna et al. 2008). Conflicting results regarding $\mathrm{COC}$ viability after ovarian tissue transport have been seen in other animal models as well. One study concluded that when equine ovaries were transported within $7 \mathrm{~h}$, temperature played no role in determining the developmental competence of retrieved 
oocytes (Ribeiro et al. 2008), whereas another group reported that transport at $4^{\circ} \mathrm{C}$ for up to $4 \mathrm{~h}$ was optimal for oocyte viability (Gomes et al. 2012). Experimental data from the feline model showed that oocytes from ovaries transported for up to $24 \mathrm{~h}$ at $4{ }^{\circ} \mathrm{C}$ were capable of producing blastocysts after in vitro fertilization (Wolfe \& Wildt 1996, Naoi et al. 2007, Evecen et al. 2009). The effect of cooler transport temperatures was also seen in a study with Iberian red deer, which showed that ovarian transport for up to $12 \mathrm{~h}$ at $5-8^{\circ} \mathrm{C}$ produced oocytes that had a higher embryonic cleavage rate than those transported at $20-25^{\circ} \mathrm{C}$ (Garcia-Alvarez et al. 2011).

In humans, the data be more conclusive that COCs do not withstand extended transport at cold temperatures well. Duncan et al. (2012) reported that although COCs can be isolated directly from fresh human ovarian tissue, there were no viable COCs recovered from tissue that had been transported for $22 \mathrm{~h}$ at $4{ }^{\circ} \mathrm{C}$. Short-term transport before OTC has also been shown to significantly compromise the oocyte maturation rate (Wilken-Jensen et al. 2014). Cryopreserved ovarian tissue from a cohort of 61 patients (0-38years of age) from Denmark's centralized cryopreservation program was examined; the tissue transport time for these samples was between 2 and $5 \mathrm{~h}$ at $4{ }^{\circ} \mathrm{C}$. A total of 682 immature oocytes within cumulus-oocyte complexes (COCs) were collected; $11 \%$ of oocytes from non-transported tissue were successfully matured in vitro to the MII stage compared with 1.4 and $4.6 \%$ of oocytes from tissue that had been transported $2-3 \mathrm{~h}$ and $4-5 \mathrm{~h}$ respectively.

Taken together, these results suggest that there are species-specific and follicle class-dependent differences in optimal ovarian tissue transport conditions. For human ovarian tissue, cold temperatures favor the preservation of preantral follicles but may not be optimal for antral follicles.

\section{Summary and future directions}

In summary, critical advances have been made in ovarian tissue transport. Preclinical studies support the use of this technique in the setting of fertility preservation for both endangered species and patients with fertility-threatening conditions (Fig. 3). Studies are ongoing to further optimize ovarian tissue transport conditions. For example, in studies using sheep ovaries as a model, addition of anti-apoptotic agents in the transport, processing and cryopreservation media improved the quality of primordial follicles post-thaw as assessed by culture and histological evaluation (Henry et al. 2016). It is especially encouraging for the field of fertility preservation that multiple human live births have been reported following transplantation of transported ovarian tissue. This technique, should it be

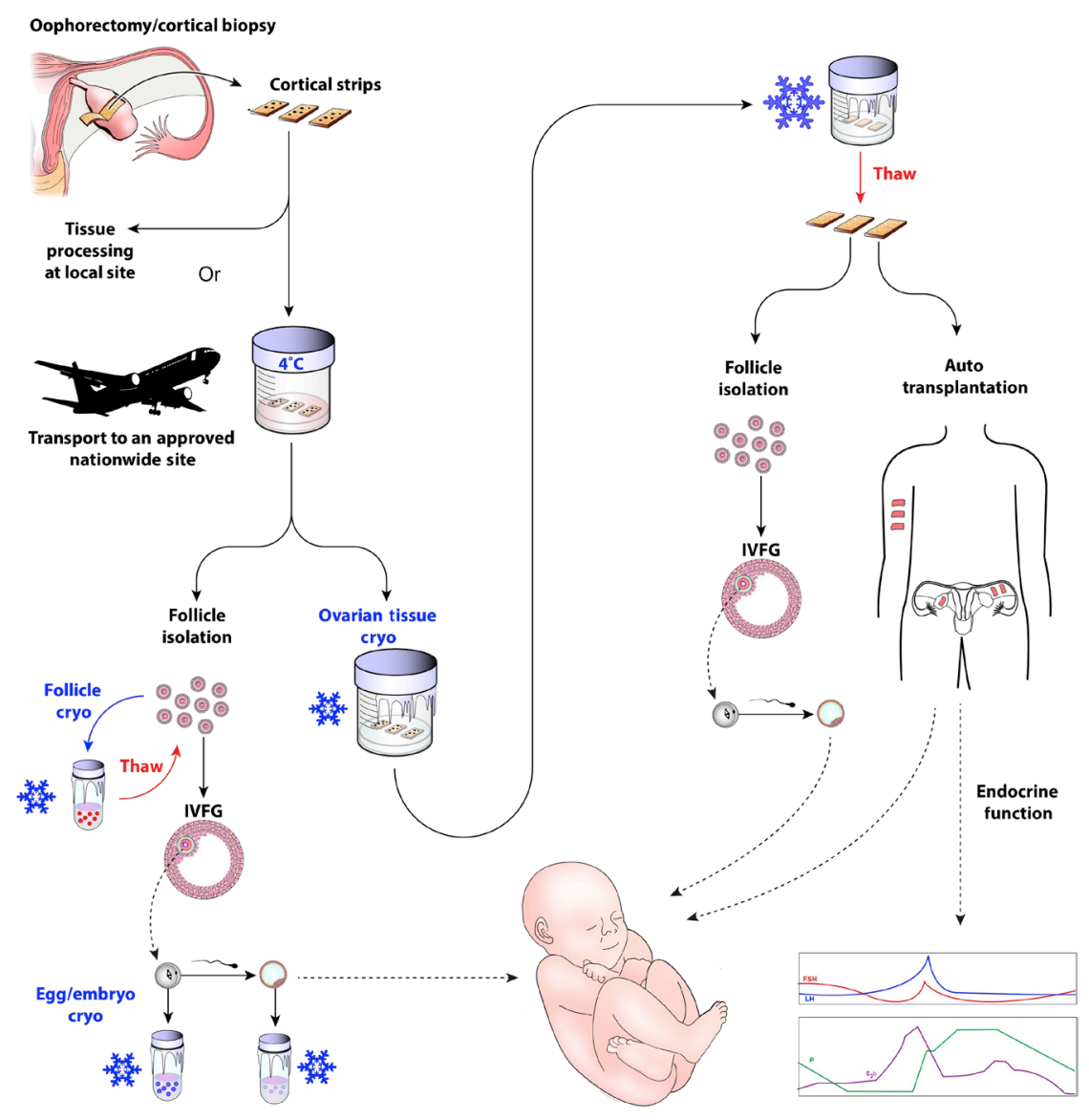

Figure 3 Schematic detailing how ovarian tissue transport integrates into clinical fertility preservation. Ovarian tissue transport would expand the fertility preservation options to those individuals who currently do not have access. Ovarian tissue that is removed as an entire organ or as a biopsy would be prepared into cortical strips upon harvesting and transported to an approved processing site. Upon arrival at the processing site, the ovarian tissue could be cryopreserved by slow freezing or vitrification methods. Following thawing, the ovarian tissue could be used for transplantation to restore endocrine function and/or fertility. Ovarian follicles could also be isolated from the thawed ovarian tissue and used for in vitro follicle growth (IVFG) to obtain mature eggs that can be used to generate embryos following in vitro fertilization or intracytoplasmic sperm injection. Another option is that follicles could be isolated directly from the transported tissue without the need for tissue cryopreservation. These isolated follicles could be cryopreserved or used for IVFG. 
implemented in clinical practice in larger countries or in those with limited resources, will increase the options for patients who are in geographic areas that lack an oncofertility program to have ovarian tissue preserved for their later use for transplantation or other emerging fertility preservation options (Fig 3).

\section{Declaration of interest}

The authors declare that there is no conflict of interest that could be perceived as prejudicing the impartiality of this review.

\section{Funding}

This work was funded through the Thomas J Watkins Endowment (TKW, Northwestern University, Chicago, IL, USA) and by the Center for Reproductive Health After Disease (P50HD076188) from the National Institutes of Health National Center for Translational Research in Reproduction and Infertility (NCTRI).

\section{Acknowledgements}

The authors would like to thank Dominique Keller for useful insight into ovarian tissue transport studies in domestic species. They also acknowledge the Aurora Packing Company, Jessica Hornick, and Jennifer Nagashima for technical assistance with the bovine, canine and feline experiments. They appreciate the work of the National Physicians Cooperative and particularly Kristin Smith and Brigid Martz. Finally, they would like to thank Stacey Tobin for editorial assistance and Stanton Fernald for his expertise in medical illustration.

\section{References}

Alves KA, Alves BG, Rocha CD, Visonna M, Mohallem RF, Gastal MO, Jacomini JO, Beletti ME, Figueiredo JR, Gambarini ML et al. 2015 Number and density of equine preantral follicles in different ovarian histological section thicknesses. Theriogenology 83 1048-1055. (doi:10.1016/j.theriogenology.2014.12.004)

American Society for Reproductive Medicine 2014 Ovarian tissue cryopreservation: a committee opinion. Fertility and Sterility 101 1237-1243. (doi:10.1016/j.fertnstert.2014.02.052)

Andersen CY, Rosendahl M, Byskov AG, Loft A, Ottosen C, Dueholm M, Schmidt KL, Andersen AN \& Ernst E 2008 Two successful pregnancies following autotransplantation of frozen/thawed ovarian tissue. Human Reproduction 23 2266-2272. (doi:10.1093/humrep/den244)

Backhus LE, Kondapalli LA, Chang RJ, Coutifaris C, Kazer R \& Woodruff TK 2007 Oncofertility consortium consensus statement: guidelines for ovarian tissue cryopreservation. Cancer Treatment and Research 138 235-239. (doi:10.1007/978-0-387-72293-1_17)

Baird DT, Webb R, Campbell BK, Harkness LM \& Gosden RG 1999 Longterm ovarian function in sheep after ovariectomy and transplantation of autografts stored at -196 C. Endocrinology 140 462-471.

Baird DT, Campbell B, de Souza C \& Telfer E 2004 Long-term ovarian function in sheep after ovariectomy and autotransplantation of cryopreserved cortical strips. European Journal of Obstetrics and Gynecology and Reproductive Biology 113 (Supplement 1) S55-S59. (doi:10.1016/j.ejogrb.2003.11.023)
Bastings L, Liebenthron J, Westphal JR, Beerendonk CC, van der Ven $\mathbf{H}$, Meinecke B, Montag M, Braat DD \& Peek R 2014 Efficacy of ovarian tissue cryopreservation in a major European center. Journal of Assisted Reproduction and Genetics 31 1003-1012. (doi:10.1007/s10815-0140239-7)

Canada AL \& Schover LR 2012 The psychosocial impact of interrupted childbearing in long-term female cancer survivors. Psychooncology $\mathbf{2 1}$ 134-143. (doi:10.1002/pon.1875)

Cantu E \& Zaas DW 2011 Organ donor management and procurement. In Organ Transplantation: A Clinical Guide, pp 53. Eds AA Klein, CJ Lewish \& CJ Madsen. Cambridge, UK: Cambridge University Press.

Chambers SK, Schover L, Nielsen L, Halford K, Clutton S, Gardiner RA, Dunn J \& Occhipinti S 2013 Couple distress after localised prostate cancer. Supportive Care in Cancer 21 2967-2976. (doi:10.1007/s00520013-1868-6)

Chen CH, Tan SJ \& Tzeng CR 2014 In vivo fate mapping of cryopreserved murine ovarian grafts. Journal of Ovarian Research 7 81. (doi:10.1186/ s13048-014-0081-7)

Chian RC, Uzelac PS \& Nargund G 2013 In vitro maturation of human immature oocytes for fertility preservation. Fertility and Sterility 99 1173-1181. (doi:10.1016/j.fertnstert.2013.01.141)

De Vos M, Smitz J \& Woodruff TK 2014 Fertility preservation in women with cancer. Lancet 384 1302-1310. (doi:10.1016/S0140-6736(14)60834-5)

Dittrich R, Lotz L, Keck G, Hoffmann I, Mueller A, Beckmann MW, van der Ven H \& Montag M 2012 Live birth after ovarian tissue autotransplantation following overnight transportation before cryopreservation. Fertility and Sterility 97 387-390. (doi:10.1016/j.fertnstert.2011.11.047)

Dittrich R, Hackl J, Lotz L, Hoffmann I \& Beckmann MW 2015 Pregnancies and live births after 20 transplantations of cryopreserved ovarian tissue in a single center. Fertility and Sterility 103 462-468. (doi:10.1016/ j.fertnstert.2014.10.045)

Dolmans MM, Marotta ML, Pirard C, Donnez J \& Donnez O 2014 Ovarian tissue cryopreservation followed by controlled ovarian stimulation and pick-up of mature oocytes does not impair the number or quality of retrieved oocytes. Journal of Ovarian Research 7 80. (doi:10.1186/ s13048-014-0080-8)

Donnez J \& Dolmans MM 2015 Ovarian cortex transplantation: 60 reported live births brings the success and worldwide expansion of the technique towards routine clinical practice. Journal of Assisted Reproduction and Genetics 32 1167-1170. (doi:10.1007/s10815-015-0544-9)

Duncan FE, Hornick JE, Lampson MA, Schultz RM, Shea LD \& Woodruff TK 2012 Chromosome cohesion decreases in human eggs with advanced maternal age. Aging Cell 11 1121-1124. (doi:10.1111/ j.1474-9726.2012.00866.x)

Duncan FE, Brannigan RE \& Woodruff TK 2014 Fertility preservation. In Yen \& Jaffe's Reproductive Endocrinology: Physiology, Pathophysiology, and Clinical Management, 7th ed. Eds JF Strauss \& RL Barbieri. Philadelphia, PA, USA: Saunders.

Duncan FE, Pavone ME, Gunn AH, Badawy S, Gracia C, Ginsberg JP, Lockart B, Gosiengfiao Y \& Woodruff TK 2015 Pediatric and teen ovarian tissue removed for cryopreservation contains follicles irrespective of age, disease diagnosis, treatment history, and specimen processing methods. Journal of Adolescent and Young Adult Oncology 4 174-183. (doi:10.1089/jayao.2015.0032)

Ernst E, Bergholdt S, Jorgensen JS \& Andersen CY 2010 The first woman to give birth to two children following transplantation of frozen/thawed ovarian tissue. Human Reproduction 25 1280-1281. (doi:10.1093/ humrep/deq033)

Ethics Committee of American Society for Reproductive Medicine 2013 Fertility preservation and reproduction in patients facing gonadotoxic therapies: a committee opinion. Fertility and Sterility 100 1224-1231. (doi:10.1016/j.fertnstert.2013.08.041)

Evecen M, Cirit U, Demir K, Karaman E, Hamzaoglu AI \& Bakirer G 2009 Developmental competence of domestic cat oocytes from ovaries stored at various durations at 4 degrees C temperature. Animal Reproduction Science 116 169-172. (doi:10.1016/j. anireprosci.2009.01.006)

Gamzatova Z, Komlichenko E, Kostareva A, Galagudza M, Ulrikh E, Zubareva T, Sheveleva T, Nezhentseva E \& Kalinina E 2014 Autotransplantation of cryopreserved ovarian tissue - effective method of fertility preservation in cancer patients. Gynecological Endocrinology 30 (Supplement 1) 43-47. (doi:10.3109/09513590.2014.945789) 
Garcia-Alvarez O, Maroto-Morales A, Berlinguer F, Fernandez-Santos MR, Esteso MC, Mermillod P, Ortiz JA, Ramon M, Perez-Guzman MD, Garde JJ et al. 2011 Effect of storage temperature during transport of ovaries on in vitro embryo production in Iberian red deer (Cervus elaphus hispanicus). Theriogenology 75 65-72. (doi:10.1016/j.theriogenology.2010.07.011)

Gomes RG, Andrade ER, Lisboa LA, Ciquini A, Barreiros TR, Fonseca NA \& Seneda MM 2012 Effect of holding medium, temperature and time on structural integrity of equine ovarian follicles during the non-breeding season. Theriogenology 78 731-736. (doi:10.1016/ j.theriogenology.2012.03.019)

Gracia C \& Woodruff TK 2012 Oncofertility Medical Practice. New York, NY, USA: Springer Science+Business Media.

Gracia CR, Chang J, Kondapalli L, Prewitt M, Carlson CA, Mattei P, Jeffers S \& Ginsberg JP 2012 Ovarian tissue cryopreservation for fertility preservation in cancer patients: successful establishment and feasibility of a multidisciplinary collaboration. Journal of Assisted Reproduction and Genetics 29 495-502. (doi:10.1007/s10815-012-9753-7)

Guibert EE, Petrenko AY, Balaban CL, Somov AY, Rodriguez JV \& Fuller BJ 2011 Organ preservation: current concepts and new strategies for the next decade. Transfusion Medicine and Hemotherapy 38 125-142. (doi:10.1159/000327033)

Guzman L, Ortega-Hrepich C, Albuz FK, Verheyen G, Devroey P, Smitz J \& De Vos M 2012 Developmental capacity of in vitro-matured human oocytes retrieved from polycystic ovary syndrome ovaries containing no follicles larger than $6 \mathrm{~mm}$. Fertility and Sterility 98 503-507 e501-e502. (doi:10.1016/j.fertnstert.2012.01.114)

Hanna C, Long C, Hinrichs K, Westhusin M \& Kraemer D 2008 Assessment of canine oocyte viability after transportation and storage under different conditions. Animal Reproduction Science 105 451-456. (doi:10.1016/ j.anireprosci.2007.12.009)

Henry L, Fransolet M, Labied S, Blacher S, Masereel MC, Foidart JM, Noel A, Nisolle M \& Munaut C 2016 Supplementation of transport and freezing media with anti-apoptotic drugs improves ovarian cortex survival. Journal of Ovarian Research 9 4. (doi:10.1186/s13048-0160216-0)

Hirshfeld-Cytron J, Gracia C \& Woodruff TK 2011 Nonmalignant diseases and treatments associated with primary ovarian failure: an expanded role for fertility preservation. Journal of Women's Health 20 1467-1477. (doi:10.1089/jwh.2010.2625)

Hornick JE, Duncan FE, Shea LD \& Woodruff TK 2012 Isolated primate primordial follicles require a rigid physical environment to survive and grow in vitro. Human Reproduction 27 1801-1810. (doi:10.1093/ humrep/der468)

Isachenko E, Isachenko V, Nawroth F, Rahimi G \& Weiss JM 2009 Effect of long-term exposure at suprazero temperatures on activity and viability of human ovarian cortex. Fertility and Sterility 91 1556-1559. (doi:10.1016/j.fertnstert.2008.09.068)

Isachenko V, Mallmann P, Petrunkina AM, Rahimi G, Nawroth F, Hancke K, Felberbaum R, Genze F, Damjanoski I \& Isachenko E 2012 Comparison of in vitro- and chorioallantoic membrane (CAM)-culture systems for cryopreserved medulla-contained human ovarian tissue. PLOS ONE 7 e32549. (doi:10.1371/journal.pone.0032549)

Isachenko V, Isachenko E, Mallmann P \& Rahimi G 2013 Increasing follicular and stromal cell proliferation in cryopreserved human ovarian tissue after long-term precooling prior to freezing: in vitro versus chorioallantoic membrane (CAM) xenotransplantation. Cell Transplantation 22 2053-2061. (doi:10.3727/096368912X658827)

Jensen AK, Kristensen SG, Macklon KT, Jeppesen JV, Fedder J, Ernst E \& Andersen CY 2015 Outcomes of transplantations of cryopreserved ovarian tissue to 41 women in Denmark. Human Reproduction 30 2838-2845. (doi:10.1093/humrep/dev230)

Jeruss JS \& Woodruff TK 2009 Preservation of fertility in patients with cancer. New England Journal of Medicine 360 902-911. (doi:10.1056/ NEJMra0801454)

Kamoshita K, Okamoto N, Nakajima M, Haino T, Sugimoto K, Okamoto A, Sugishita Y \& Suzuki N 2016 Investigation of in vitro parameters and fertility of mouse ovary after storage at an optimal temperature and duration for transportation. Human Reproduction 31 774-781. (doi:10.1093/humrep/dew023)

Laronda MM, Duncan FE, Hornick JE, Xu M, Pahnke JE, Whelan KA, Shea LD \& Woodruff TK 2014 Alginate encapsulation supports the growth and differentiation of human primordial follicles within ovarian cortical tissue. Journal of Assisted Reproduction and Genetics 31 1013-1028. (doi:10.1007/s10815-014-0252-x)

Lawson AK, Klock SC, Pavone ME, Hirshfeld-Cytron J, Smith KN \& Kazer RR 2014 Prospective study of depression and anxiety in female fertility preservation and infertility patients. Fertility and Sterility $\mathbf{1 0 2}$ 1377-1384. (doi:10.1016/j.fertnstert.2014.07.765)

Levine JM, Kelvin JF, Quinn GP \& Gracia CR 2015 Infertility in reproductiveage female cancer survivors. Cancer 121 1532-1539. (doi:10.1002/ cncr.29181)

Lewis PE, Sheng M, Rhodes MM, Jackson KE \& Schover LR 2012 Psychosocial concerns of young African American breast cancer survivors. Journal of Psychosocial Oncology 30 168-184. (doi:10.1080/ 07347332.2011.651259)

Lima GL, Costa LL, Cavalcanti DM, Rodrigues CM, Freire FA, Fontenele-Neto JD \& Silva AR 2010 Short-term storage of canine preantral ovarian follicles using a powdered coconut water (ACP)based medium. Theriogenology 74 146-152. (doi:10.1016/ j.theriogenology.2010.01.025)

Lobo RA 2005 Potential options for preservation of fertility in women. New England Journal of Medicine 353 64-73. (doi:10.1056/ NEJMra043475)

Lopes CA, dos Santos RR, Celestino JJ, Melo MA, Chaves RN, Campello CC, Silva JR, Bao SN, Jewgenow K \& de Figueiredo JR 2009 Short-term preservation of canine preantral follicles: effects of temperature, medium and time. Animal Reproduction Science 115 201-214. (doi:10.1016/ j.anireprosci.2008.12.016)

Loren AW, Mangu PB, Beck LN, Brennan L, Magdalinski AJ, Partridge AH, Quinn G, Wallace WH, Oktay K \& American Society of Clinical Oncology 2013 Fertility preservation for patients with cancer: American Society of Clinical Oncology clinical practice guideline update. Journal of Clinical Oncology 31 2500-2510. (doi:10.1200/JCO.2013.49.2678)

Lucci CM, Kacinskis MA, Rumpf R \& Bao SN 2004 Effects of lowered temperatures and media on short-term preservation of zebu (Bos indicus) preantral ovarian follicles. Theriogenology 61 461-472. (doi:10.1016/ S0093-691X(03)00226-7)

Meirow D, Levron J, Eldar-Geva T, Hardan I, Fridman E, Zalel Y, Schiff E \& Dor J 2005 Pregnancy after transplantation of cryopreserved ovarian tissue in a patient with ovarian failure after chemotherapy. New England Journal of Medicine 353 318-321. (doi:10.1056/NEJMc055237)

Milbury K, Cohen L, Jenkins R, Skibber JM \& Schover LR 2013 The association between psychosocial and medical factors with long-term sexual dysfunction after treatment for colorectal cancer. Supportive Care in Cancer 21 793-802. (doi:10.1007/s00520-012-1582-9)

Morrow PK, Broxson AC, Munsell MF, Basen-Enquist K, Rosenblum CK, Schover LR, Nguyen LH, Hsu L, Castillo L, Hahn KM et al. 2014 Effect of age and race on quality of life in young breast cancer survivors. Clinical Breast Cancer 14 e21-e31. (doi:10.1016/j.clbc.2013.10.003)

Muller A, Keller K, Wacker J, Dittrich R, Keck G, Montag M, Van der Ven H, Wachter D, Beckmann MW \& Distler W 2012 Retransplantation of cryopreserved ovarian tissue: the first live birth in Germany. Deutsches Ärzteblatt International 109 8-13.

Naoi H, Otoi T, Shimamura T, Karja NW, Agung B, Shimizu R, Taniguchi M \& Nagai T 2007 Developmental competence of cat oocytes from ovaries stored at various temperature for $24 \mathrm{~h}$. Journal of Reproduction and Development 53 271-277. (doi:10.1262/jrd.18115)

Onions VI, Mitchell MR, Campbell BK \& Webb R 2008 Ovarian tissue viability following whole ovine ovary cryopreservation: assessing the effects of sphingosine-1-phosphate inclusion. Human Reproduction 23 606-618. (doi:10.1093/humrep/dem414)

Revel A, Koler M, Simon A, Lewin A, Laufer N \& Safran A 2003 Oocyte collection during cryopreservation of the ovarian cortex. Fertility and Sterility 79 1237-1239. (doi:10.1016/S0015-0282(02)04963-4)

Ribeiro BI, Love LB, Choi YH \& Hinrichs K 2008 Transport of equine ovaries for assisted reproduction. Animal Reproduction Science $\mathbf{1 0 8}$ 171-179. (doi:10.1016/j.anireprosci.2007.08.001)

Rodriguez SB \& Campo-Engelstein L 2011 Conceiving wholeness: women, motherhood, and ovarian transplantation, 1902 and 2004. Perspectives in Biology and Medicine 54 409-416. (doi:10.1353/pbm.2011.0036)

Rosendahl M, Schmidt KT, Ernst E, Rasmussen PE, Loft A, Byskov AG, Andersen AN \& Andersen CY 2011 Cryopreservation of ovarian tissue for a decade in Denmark: a view of the technique. Reproductive BioMedicine Online 22 162-171. (doi:10.1016/j. rbmo.2010.10.015) 
Ross L, Chung K \& Macdonald H 2014 Fertility preservation in the female cancer patient. Journal of Surgical Oncology 110 907-911. (doi:10.1002/ jso.23754)

Salih SM, Ringelstetter AK, Elsarrag MZ, Abbott DH \& Roti EC 2015 Dexrazoxane abrogates acute doxorubicin toxicity in marmoset ovary. Biology of Reproduction 92 73. (doi:10.1095/ biolreprod.114.119495)

Schmidt KL, Byskov AG, Nyboe Andersen A, Muller J \& Yding Andersen C 2003a Density and distribution of primordial follicles in single pieces of cortex from 21 patients and in individual pieces of cortex from three entire human ovaries. Human Reproduction 18 1158-1164. (doi:10.1093/humrep/deg246)

Schmidt KL, Ernst E, Byskov AG, Nyboe Andersen A \& Yding Andersen C $2003 \mathrm{~b}$ Survival of primordial follicles following prolonged transportation of ovarian tissue prior to cryopreservation. Human Reproduction 18 2654-2659. (doi:10.1093/humrep/deg500)

Segers I, Mateizel I, Van Moer E, Smitz J, Tournaye H, Verheyen G \& De Vos M 2015 In vitro maturation (IVM) of oocytes recovered from ovariectomy specimens in the laboratory: a promising 'ex vivo' method of oocyte cryopreservation resulting in the first report of an ongoing pregnancy in Europe. Journal of Assisted Reproduction and Genetics 32 1221-1231. (doi:10.1007/s10815-015-0528-9)

Silva JR, Lucci CM, Carvalho FC, Bao SN, Costa SH, Santos RR \& Figueiredo JR 2000 Effect of coconut water and Braun-Collins solutions at different temperatures and incubation times on the morphology of goat preantral follicles preserved in vitro. Theriogenology 54 809-822. (doi:10.1016/S0093-691X(00)00392-7)

Smitz J, Dolmans MM, Donnez J, Fortune JE, Hovatta O, Jewgenow K, Picton HM, Plancha C, Shea LD, Stouffer RL et al. 2010 Current achievements and future research directions in ovarian tissue culture, in vitro follicle development and transplantation: implications for fertility preservation. Human Reproduction Update 16 395-414. (doi:10.1093/ humupd/dmp056)

Stoop D, Cobo A \& Silber S 2014 Fertility preservation for age-related fertility decline. Lancet 384 1311-1319. (doi:10.1016/S01406736(14)61261-7)

Suzuki N, Yoshioka N, Takae S, Sugishita Y, Tamura M, Hashimoto S, Morimoto Y \& Kawamura K 2015 Successful fertility preservation following ovarian tissue vitrification in patients with primary ovarian insufficiency. Human Reproduction 30 608-615. (doi:10.1093/humrep/deu353)

Tas M, Evecen M, Ozdas OB, Cirit U, Demir K, Birler S \& Pabuccuoglu S 2006 Effect of transport and storage temperature of ovaries on in vitro maturation of bitch oocytes. Animal Reproduction Science 96 30-34. (doi:10.1016/j.anireprosci.2005.11.001)
Ting AY, Yeoman RR, Campos JR, Lawson MS, Mullen SF, Fahy GM \& Zelinski MB 2013 Morphological and functional preservation of pre-antral follicles after vitrification of macaque ovarian tissue in a closed system. Human Reproduction 28 1267-1279. (doi:10.1093/ humrep/det032)

Uzelac PS, Delaney AA, Christensen GL, Bohler HC \& Nakajima ST 2015 Live birth following in vitro maturation of oocytes retrieved from extracorporeal ovarian tissue aspiration and embryo cryopreservation for 5 years. Fertility and Sterility 104 1258-1260. (doi:10.1016/j. fertnstert.2015.07.1148)

Waimey KE, Duncan FE, Su HI, Smith K, Wallach H, Jona K, Coutifaris C, Gracia CR, Shea LD, Brannigan RE et al. 2013 Future directions in oncofertility and fertility preservation: a report from the 2011 oncofertility consortium conference. Journal of Adolescent and Young Adult Oncology 2 25-30. (doi:10.1089/jayao.2012.0035)

Wallace WH, Smith AG, Kelsey TW, Edgar AE \& Anderson RA 2014 Fertility preservation for girls and young women with cancer: population-based validation of criteria for ovarian tissue cryopreservation. Lancet Oncology 15 1129-1136. (doi:10.1016/ S1470-2045(14)70334-1)

Wang X, Al Naib A, Sun DW \& Lonergan P 2010 Membrane permeability characteristics of bovine oocytes and development of a step-wise cryoprotectant adding and diluting protocol. Cryobiology 61 58-65. (doi:10.1016/j.cryobiol.2010.05.001)

Wilken-Jensen HN, Kristensen SG, Jeppesen JV \& Yding Andersen C 2014 Developmental competence of oocytes isolated from surplus medulla tissue in connection with cryopreservation of ovarian tissue for fertility preservation. Acta Obstetricia et Gynecologica Scandinavica 93 32-37. (doi:10.1111/aogs.12264)

Wolfe BA \& Wildt DE 1996 Development to blastocysts of domestic cat oocytes matured and fertilized in vitro after prolonged cold storage. Journal of Reproduction and Fertility 106 135-141. (doi:10.1530/ jrf.0.1060135)

Woodruff TK 2010 The Oncofertility Consortium--addressing fertility in young people with cancer. Nature Reviews Clinical Oncology 7 466-475. (doi:10.1038/nrclinonc.2010.81)

Received 17 December 2015

First decision 2 February 2016

Revised manuscript received 28 June 2016

Accepted 4 August 2016 